\title{
ANALISIS PENERAPAN SEGMENTASI, TARGETING, POSITIONING (STP) DAN PROMOSI PEMASARAN SEBAGAI SOLUSI MENINGKATKAN PERKEMBANGAN UMKM KOTA BENGKAYANG
}

\author{
Blasius Manggu( $\mathbb{(}^{1)}$ dan Sabinus Beni $i^{2)}$ \\ ${ }^{1}$ Manajemen, Institut Shanti Bhuana \\ ${ }^{2}$ Kewirausahaan, Institut Shanti Bhuana \\ 1,2 Jl. Bukit Karmel No. 1 Bengkayang 79211 \\ E-mail : Blasius@shantibhuana.ac.id ${ }^{1)}$, Beni@shantibhuana.ac.id ${ }^{2)}$
}

\begin{abstract}
ABSTRAK
Penelitian ini bertujuan untuk mengetahui peran pentingnya segmentasi, tergenting, positioning dan promosi pemasaran pada Usaha Mikro Kecil Menengah (UMKM) di kota Bengkayang, sehingga dapat memudahkan menyusun strategi pemasaran. Pasar dapat dipetakan berdasarkan geografis, demografis, kelas ekonomi, psikografis. Membidik pasar mana yang dituju agar program pemasaran perusahaan sesuai dengan karakteristik. Penempatan produk di benak konsumen melalui kinerja produk, pelayanan, harga, inovasi produk agar konsumen selalu menggunakan produk kita. Usaha Mikro Kecil Menengah (UMKM) di kota Bengkayang terdiri dari bermacam macam jenis usaha dan selama ini usaha yang mereka jalankan belum fokus pada target market berdasarkan karakteristik wilayah, demografi, psikografis, pasar yang dituju belum terarah masih memusatkan pada pasar secara menyeluruh, sementara dalam melayani pasar produk yang diunggulkan masing-masing UMKM masih kurang, kualitas pelayanan masih terbatas. Program pemasaran dalam segi promosi belum begitu dijalankan dengan baik, karena minimnya pengetahuan dan strategi yang dijalankan untuk menghadapi pasar masih sebatas jual dan laku belum mengarah kepada pengembangan usaha untuk bersaing. Jenis penelitian ini dengan pendekatan kualitatif, sedangkan metode dalam penelitian ini yaitu dengan melaksanakan observasi ke lapangan, dengan mendatangi beberapa UMKM yang bergerak di bidang usaha dagang, jasa keuangan, toko kelontong, kedai kopi, sebagai sampel, serta studi literatur, dokumentasi, sehinga dapat diperoleh data untuk dianalisis guna mengetahui penerapan segmentasi, targeting, positioning dan promosi pemasaran untuk meningkatkan perkembangan UMKM di kota Bengkayang.
\end{abstract}

Kata Kunci : Segmentasi, Targeting, Positioning, Promosi Pemasaran, UMKM, Bengkayang

\section{PENDAhUluan}

Mencari laba yang semaksimal mungkin adalah tujuan berdirinya perusahaan. Kemampuan perusahaan dalam mencapai visi dan misinya sangat dipengaruhi oleh kinerja produk yang dihasilkan. Kinerja produk ini meliputi kualitas, pelayanan, brand, dapat membuat konsumen lebih percaya dan memakainya berulang ulang. Menjual produk dengan harga sesuai dengan kualitas dan yang diinginkan konsumen dapat mampu bersaing dengan kompetitor lainnya. (Assari, 2013) mengemukakan strategi pemasaran adalah serangkaian tujuan dan sasaran, kebijakan dan aturan yang memberi arah kepada usaha pemasaran perusahaan dari waktu ke watu, pada masing-masing tingkatan dan acuan serta alokasinya, terutama sebagai tanggapan perusahaan dalam menghadapi lingkungan dan keadaan persaingan yang selalu berubah. Serangkaian tujuan, saran, kebijakan, dan memberi arah pada usaha promosi, produksi, distribusi dan harga tujuan dari strategi pemasaran. Pemasaran merupakan kegiatan terpadu dari bagian usaha atau bisnis yang di dalamnya berisikan perencanaan, penentuan harga barang atau jasa, berbagai strategi promosi, pendistribusian barang atau jasa dengan tujuan untuk memenuhi kebutuhan konsumen hingga konsumen puas terhadap pelayanan yang diberikan oleh perusahaan (Stanton, 2013).

Pemasaran dapat dikatakan bagian terpenting untuk bertahap dalam pasar dan bersaing dengan pesaing lainnya. Seringnya perusahaan gagal dalam pemasaran, dikarenakan konsep dan penerapannya serta faktor pendukung lainnya tidak dapat berjalan dengan baik. Penyebab pemasar belum tahu dan mengerti tentang segmentasi, target, dan posisi, begitu juga dalam menyusun strategi bauran pemasaran, kurang paham akan strategi dalam segmentasi, target yang dituju, serta janji yang diberikan kepada konsumen. Ketakpahaman ini sering kali pemasar salah dalam mengejar target, juga menetapkan elemen bauran pemasaran, pemosisian akan produk di benak konsumen jauh dari yang diinginkan perusahaan, janji membingungkan konsumen, janji berlebihan, janji meragukan, janji kerendahan kepada konsumen (Durianto, dkk, 2013)

Kinerja dalam pemasaran yang maksimal, pertama kali dilakukan adalah melakukan segmentasi pasar atas produk yang dihasilkan. Demografis, gaya hidup (psikografis), kelas ekonomi menengah dan sedang, 
merupakan pembagian pasar yang akan dimasuki. Targeting atau membidik pasar melalui analis dan survei pasar merupakan langkah selanjutnya setelah segmentasi. Serangkaian program pemasaran yang dilaksanakan harus sesuai dengan karakteristik pasar sasaran yang hendak dituju. Langkah berikutnya adalah melakukan positioning produk. Langkah ini adalah menciptakan keunikan posisi produk dalam benak persepsi pelanggan potensial yang akan dibidik.

Penerapan Segmenting, Targeting, Positioning (STP) yang tepat tentu saja akan memudahkan perusahaan dalam menyusun program kegiatan pemasaran. Terkait dengan hal itu, sebenarnya kegiatan dalam pemasaran menyangkut empat jenis tindakan yaitu tindakan mengenai produk, harga, distribusi dan promosi. Dari keempat jenis tindakan tersebut di dalamnya perlu dipikirkan strategi-strategi yang berkaitan dengan keempat kegiatan tersebut, baik secara individu maupun secara keseluruhan. Kombinasi dari strategi produk, harga, distribusi dan promosi dalam mencapai tujuan pemasaran dinamakan marketing mix atau bauran pemasaran (Rismiati dan Suratno, 2001). Tanpa mengesampingkan tiga strategi lainnya dalam unsur marketing mix atau bauran pemasaran, strategi harga perlu mendapatkan perhatian besar dari perusahaan. Setiap perusahaan selalu mengejar keuntungan guna kesinambungan produksi.

Era globalisasi mengakibatkan persaingan di segala bidang usaha menjadi semakin ketat. Menghadapi hal tersebut maka perusahaan harus berorientasi pada pemasaran /marketing oriented di mana semua kegiatan perusahaan diarahkan untuk memenuhi keinginan konsumen sehingga tercipta suatu kepuasan. Dengan terpenuhinya keinginan yang pada akhirnya memberikan kepuasan kepada konsumen, perusahaan tidak perlu takut akan kehilangan konsumen walaupun di tengah banyak pesaing. Salah satu contoh bidang usaha yang menunjukkan adanya persaingan yang ketat adalah Usaha Mikro Kecil Menengah (UMKM), Usaha Mikro Kecil Menengah (UMKM) merupakan salah satu bagian penting dari perekonomian suatu negara maupun daerah, begitu juga dengan negara Indonesia Usaha Mikro Kecil Menengah sangat memiliki peranan penting dalam lajunya perekonomian masyarakat. (Undang-Undang No. 70 Tahun 2008 Tentang Usaha Mikro Kecil Menengah) usaha ekonomi produktif yang berdiri sendiri, yang dilakukan oleh orang perseorangan atau badan usaha yang bukan merupakan anak perusahaan atau cabang perusahaan yang dimiliki, dikuasai atau menjadi bagian baik langsung maupun tidak langsung dengan usaha kecil atau usaha besar, juga sangat membantu negara/ pemerintah dalam hal penciptaan lapangan kerja baru dan lewat Usaha Kecil Menengah juga banyak tercipta unit kerja baru yang menggunakan tenaga-tenaga baru yang dapat mendukung pendapatan rumah tangga. Selain dari itu Usaha Mikro Kecil Menengah juga memiliki fleksibilitas yang tinggi jika dibandingkan dengan usaha yang berkapasitas lebih besar.
Usaha Mikro Kecil Menengah perlu perhatian yang khusus dan didukung oleh informasi yang akurat, agar terjadi link bisnis yang terarah antara para pelaku usaha kecil dan menengah dengan elemen daya saing, yaitu jaringan pasar. Oleh karena itu diperlukan suatu kebijakan yang tepat dalam menyusun dan menetapkan strategi segmenting, targeting, promosi agar usahanya bisa tetap bertahan dan dapat bersaing dengan bidang usaha lainnya. Dalam perusahaan Segmentasi, Targeting, Positioning dan Promosi sangatlah penting, untuk meraih pangsa pasar di tengah pasar yang sangat kompetitif ini. (Sitohang, 2017) dalam penelitian sebelumnya Strategi Segmenting, Targeting, dan Positionig pada perusahaan Asuransi PT. (Persero) Jiwasraya, Pekanbaru, membagi pasarnya berdasarkan demografis berdasarkan latar belakang pekerjaan ada pegawai swasta, mahasiswa dan dokter dan pegawai negeri. Dalam menentukan target pasar, perusahaan menerapkan formula cakupan pasar penuh yang berarti perusahaan melayani seluruh pelanggan tanpa memperhatikan aspek apapun. Dalam memposisikan perusahaan kedalam pikiran konsumen perusahaan selalu menunjukkan bahwa perusahaan ini juga selalu dijalankan untuk kepentingan umum, memberikan manfaat, dijamin setelah penjualan dan harga produk yang terjangkau, teknologi yang baik akan berdampak pada kualitas maupun kuantitas pembangunan itu sendiri. Menurut (Wijaya \& Sirine, 2016) dalam penelitiannya tentang strategi segmenting, targeting, positioning serta strategi harga pada perusahaan kecap blekok di cilacap segmen pasar yang dituju adalah kelas sosial menengah ke bawah, target pasar yang dipilih berupa konsentrasi segmen pasar tunggal, pemosisian produk kelas menengah ke bawah dengan kualitas tinggi. Usaha Mikro Kecil Menengah (UMKM) di Kecamatan Bengkayang selama ini belum menunjukkan pemilahan pasar yang di tuju baik dari segi demografis, psikografis, geografis, begitu juga untuk meraih konsumen yang dituju penempatan produk di benak konsumen masih belum dirasa belum, serta target pasar yang dituju belum di rencanakan dengan baik, sehingga perkembangannya belum menunjukkan adanya peningkatan. Untuk promosi hasil usahanya sebagian masih mengandalkan cara-cara tradisional, dan belum tersentuh oleh perkembangan teknologi dan informasi.

\section{RUANG LINGKUP}

Dalam penelitian ini permasalahan mencakup Belum maksimalnya penerapan segmentasi targeting, segmenting, positioning dan promosi penjualan untuk meningkatkan perkembangan Usaha Mikro Kecil Menengah.

1. Bagaimana penerapan Segmentasi, Targeting, Positioning dan Promosi Pemasaran Usaha Mikro Kecil Menengah di Kota Bengkayang dalam rangka meningkatkan perkembangan UMKM

2. Membatasi penerapan Segmentasi, Targeting, Positioning dan Promosi Pemasaran untuk meningkatkan perkembangan UMKM 
3. Melalui penelitian ini dapat dipetakan strategi pemasaran Usaha Mikro Kecil Menengah di Kota Bengkayang sebagai solusi untuk meningkatkan perkembangan usahanya

\section{BAHAN DAN METODE}

Berikut disajikan bahan dan metode dalam penelitian ini, yang terdiri dari dua bagian kajian yakni kajian teori dan metodologi penelitian

\subsection{Bahan Kajian}

Bahan kajian dalam penelitian ini meliputi kajian tentang strategi pemasaran, penerapan segmentasi, penerapan targeting, penerapan positioning, dan promosi pemasaran

\section{Strategi Pemasaran}

Strategi pemasaran pada gambar 1 adalah untuk memasarkan suatu produk, apakah itu barang atau jasa, menggunakan pola rencana dan taktik tertentu sehingga penjualan menjadi lebih tinggi. Dikatakan juga bahwa strategi pemasaran merupakan serangkaian upaya yang dilakukan oleh perusahaan dalam rangka mencapai tujuan tertentu, karena potensi untuk menjual proposisi terbatas pada jumlah orang tang mengetahui ini. Strategi perusahaan memiliki peran penting dalam suatu perusahaan atau bisnis karena berfungsi untuk menentukan nilai perusahaan, baik harga barang maupun jasa. Strategi pemasaran (Boon, 2008) adalah program keseluruhan dalam menentukan target pasar dan memuaskan konsumen dengan membangun kombinasi elemen dari bauran pemasaran, produk, distribusi, harga. Tujuan strategi pemasaran 1. Untuk meningkatkan kualitas koordinasi antar individu dalam tim pemasaran, 2. Sebagai ukuran hasil pemasaran atas dasar standar pencapaian yang sudah ditentukan. 3. Sebagai dasar logis dalam langkah pengambilan keputusan pemasaran. 4. Untuk meningkatkan kemampuan beradaptasi apabila terdapat perubahan. Langkah-langkah dalam strategi pemasaran

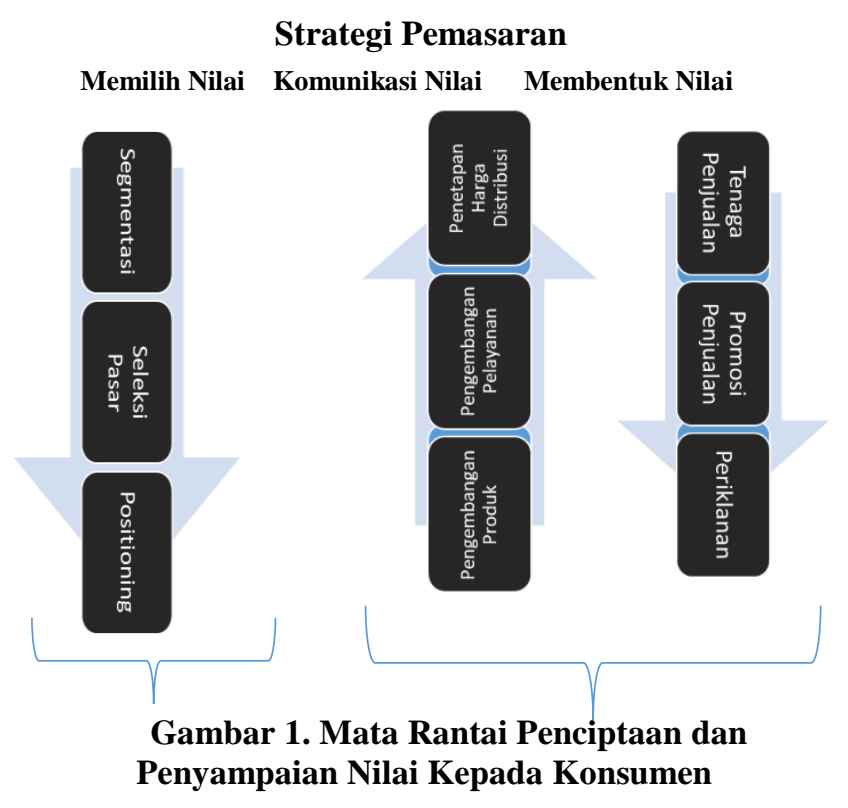

2. Penerapan Segmentasi

Segmentasi adalah proses pembagian pasar menjadi kelompok-kelompok yang berbeda karakteristik maupun kebutuhan. Firmansyah (2019) segmentasi merupakan proses mengelompokkan pasar yang heterogen kedalam satu kelompok yang memiliki karakteristik dan kebutuhan yang sama. Salah satu metode dalam melaksanakan segmentasi pasar adalah dengan cara membedahkan segmen pasar berdasarkan 4 (empat) kategori diantaranya adalah, Geografis, segmentasi ini membagi pasar dalam beberapa bagian seperti negara, bagian, wilayah, kota dan desa yang dipandang sangat potensial., Demografis, dalam demografis pasar dibagi menjadi grup-grup dengan dasar pembagian seperti usia, jenis kelamin, tingkat pendapatan, tingkat pendidikan dan agama guna untuk memudahkan jangkauan dan relatif lebih murah untuk mengidentifikasi pasar sasaran, informasi demografi memberikan insight tentang trend yang sedang terjadi, meski tidak bisa digunakan untuk meramalkan perilaku konsumen namun penggunaan informasi Demografi ini dapat melihat perubahan permintaan aneka produk dan dapat digunakan untuk mengevaluasi kampanye-kampanye pemasaran. Psikografis, Dalam segmentasi psikografis ini konsumen dapat di observasi dalam kelas social (social class), gaya hidup (lifestyle), nilai-nilai kehidupan yang dianut (value), dan kepribadian (personality), dan Segmentasi perilaku, segmentasi perilaku konsumen dibagi menjadi beberapa kelompok-kelompok berdasarkan pengetahuan, sikap, pemakaian, atau tanggapan mereka terhadap suatu produk. Banyak pemasar yakin bahwa variabel perilaku kejadian, manfaat, status pemakai, tingkat pemakaian, status kesetiaan, tahapan kesiapan pembeli dan sikap merupakan titik awal terbaik dalam membentuk segmen pasar. Maliki, (2018), kelas sosial dapat dibedakan menurut kekayaan, kekuasaan, kehormatan, dan ilmu pengetahuan. Menurut (Keller \& Kotler, 2012), gaya 
hidup dapat dicerminkan melalui aktivitas, hobby, dan pendapat.

\section{Penetapan Targeting}

Merupakan proses evaluasi dan pemilihan beberapa segmen (Kotler, 2011) pasar dari hasil segmentasi. Ada 4 macam strategi dalam menerapkan segmen pasar yaitu

1) Undifferentiated Marketing, dalam strategi ini perusahaan mencoba untuk mengembangkan produk tunggal yang dapat memenuhi keinginan semua konsumen atau segmen pasar yang terbesar

2) Differentiated Marketing, dalam strategi ini, perusahaan berusaha untuk mengidentifikasi kelompok-kelompok konsumen tertentu dengan membagi pasar ke dalam dua kelompok atau lebih. Kemudian perusahaan memproduksi barang dan program pemasaran yang berbeda untuk setiap kelompok.

3) Concentrated marketing adalah suatu strategi dimana perusahaan hanya melayani satu atau beberapa kelompok konsumen. Alternatif ini sangat menarik terutama jika sumber daya perusahaan terbatas.

Selain strategi yang diatas tadi perusahaan juga dapat memilih pasar sasaran yang optimal dengan melihat karakteristik yang dapat dipenuhi untuk mendapatkan pasar sasaran diantaranya adalah a) Responsif b) Potensi penjualan harus cukup luas c) Pertumbuhan memadai d) Jangkauan media. Mata rantai konsumsi dikenal dengan proses AIDA, yaitu Awareness (konsumen dasar terhadap keberadaan suatu produk/merk), Inters (menaruh minat), Desired (menghendaki, merasa membutuhkan) dan action (membeli).

\section{Positioning}

Merupakan cara menempatkan produk ditempat yang jelas, berbeda dan diinginkan oleh pangsa pasar yang dituju (Kotler, 2012). Ada 3 tahap dalam menentukan positioning, yakni mengumpulkan perbedaan nilai pelanggan untuk membangun posisi dan memilih keseluruhan. Fandy (2011) menyatakan ada tujuh pendekatan yang dapat digunakan untuk melakukan positioning yaitu :

1) Positioning berdasarkan atribut, ciri-ciri atau manfaat bagi pelanggan (attribute positioning), yaitu dengan jalan mengasosiasikan suatu produk dengan manfaat bagi pelanggan.

2) Positioning berdasarkan harga dan kualitas (price and quality positioning), yaitu positioning yang berusaha menciptakan kesan/citra berkualitas tinggi lewat harga tinggi atau sebaliknya menekankan harga murah sebagai indicator nilai.

3) Positioning yang dilandasi dengan aspek penggunaan atau aplikasi (use application) yaitu seperangkat nilai-nilai penggunaan yang digunakan sebagai unsur yang ditonjolkan dibandingkan pesaingnya.

4) Positioning berdasarkan pemakai produk (use positioning) yaitu mengaitkan produk dengan kepribadian atau tipe pemakai.
5) Positioning berdasarkan kelas produk tertentu (product class positioning), misalnya permen Kopiko yang diposisikan sebagai kopi dalam bentuk permen, bukan permen rasa kopi.

6) Positioning berdasarkan manfaat (benefit positioning) yaitu menghubungkan merek dengan salah satu karakteristik atau fitur produk yang diharapkan bisa dirasakan sebagai keunggulan yang diinginkan oleh konsumen.

7) Positioning berkenaan dengan pesaing (competitor positioning) yaitu dikaitkan dengan posisi persaingan terhadap pesaing utama

5. Strategi Pemasaran dengan Mengembangkan Bauran Pemasaran

Bauran Pemasaran adalah seperangkat alat pemasaran yang digunakan perusahaan untuk mencapai tujuan pemasarannya dalam pasar sasaran (Kotler, 2012). Ada empat unsur dalam elemen bauran pemasaran tersebut adalah;

1. Product (Produk)

Merupakan alat bauran pemasaran yang paling mendasar dan biasanya penawaran berwujud kualitas, keanekaragaman produk, desain, bentuk, merk, kemasan, ukuran, pelayanan, jaminan, pengembalian produk

2. Place (Tempat)

Termasuk berbagai kegiatan yang dilakukan perusahaan untuk membuat produk dapat diperoleh dan tersedia bagi pelanggan sasaran. Variabel tempat ini biasanya meliputi saluran, ruang lingkup, penyortiran, lokasi, persediaan, dan pengangkutan

3. Promotion (Promosi)

Meliputi semua kegiatan yang dilakukan perusahaan untuk mengkomunikasikan dan mempromosikan produknya kepada pasar sasaran, yang dimana variabel ini terdiri dari promosi penjualan, iklan, usaha penjualan, hubungan masyarakat dan pemasaran langsung. Promosi dilakukan untuk mendukung penjualan. Promosi mengkomunikasikan informasi yang bermanfaat tentang suatu produk atau jasa mempengaruhi pembeli potensial. Produk atas jasa yang dihasilkan dapat diketahui pelanggan perlu upaya untuk mengkomunikasikan produk atau jasa tersebut melalui kegiatan promosi. Oleh karena itu, (Kotler, 2011) mengartikan promosi adalah semua kegiatan yang dilakukan perusahaan untuk mengkomunikasikan produk pada pasar sasaran. Tujuan promosi adalah memberitahukan (informing), membujuk (persuading), mengingatkan (remainding) dan pemantapan (reinforcement). Fungsi promosi adalah mencari dan mendapatkan perhatian dari calon pembeli, menumbuhkan ketertarikan atau jasa kepada calon pembeli dan mengembangkan hasrat calon pembeli untuk memilih produk atau jasa yang ditawarkan. Bauran promosi (promotion mix) terdiri dari iklan, penjualan perorangan, promosi penjualan, hubungan masyarakat, pemasaran langsung. Faktor- 
faktor yang menjadi pertimbangan perusahaan dalam memilih bauran promosi adalah jumlah dana yang tersedia, jenis produk, sifat pasar, dan tahap daur hidup produk (Kotler, 2012)

\subsection{Metode}

Jenis Penelitian ini menggunakan pendekatan secara kualitatif deskriptif, yakni suatu cara yang digunakan untuk memahami sifat-sifat dari suatu fenomena objek yang diteliti sehingga dapat diketahui dan analis pokok permasalahan yang muncul dan diambil alternatif pemecahannya. Tipe penelitian bersifat deskriptif, yakni metode yang meneliti status sekelompok manusia suatu objek, suatu kondisi, suatu sistem pemikiran pada saat masa sekarang. Tujuan penelitian ini membuat deskripsi gambaran secara sistematika, faktual dan akurat mengenai fakta-fakta, berdasarkan observasi pada UMKM di Kota Bengkayang. Dalam penelitian ini dapat memfokuskan masalah terlebih dahulu supaya tidak terjadi perluasan permasalahan yang nantinya tidak sesuai dengan tujuan penelitian ini. Tahapan dalam penelitian ini di gambarkan pada gambar 2, diantaranya:

1. Mengidentifikasi sejauh mana perkembangan Usaha Mikro Kecil dan Menengah (UMKM), serta faktor penghambat dalam menjalankan usahanya.

2. Mengidentifikasi sejumlah Usaha Mikro Kecil \& Menengah di Kota Bengkayang yang menerapkan aspek segmentasi, targeting, dan pemosisian UMKM sehingga dengan identifikasi nantinya peneliti dapat membuat suatu kesimpulan tujuan penelitian ini.

3. Studi literatur, kajian mendalam tentang penerapan segmentasi, targeting, positioning, data literatur, buku, jurnal maupun text book.

4. Data diolah berdasarkan hasil observasi beberapa UMKM di Kota Bengkayang antara lain UMKM perdagangan pertanian, Sembako, Kedai, Jasa Keuangan studi kelayakan terkait aspek penerapan segmentasi, targeting, positioning serta indikator yang mempengaruhi pada UMKM di Kota Bengkayang

5. Menganalisis, sejauh mana hasil pengolahan data terkait penerapan segmentasi (lihat tabel 1), targeting, positioning dan promosi pemasaran

6. Saran serta kesimpulan terkait hasil penelitian.
Tabel 1. Penerapan Segmentasi, Targeting, Positioning UMKM Kota Bengkayang

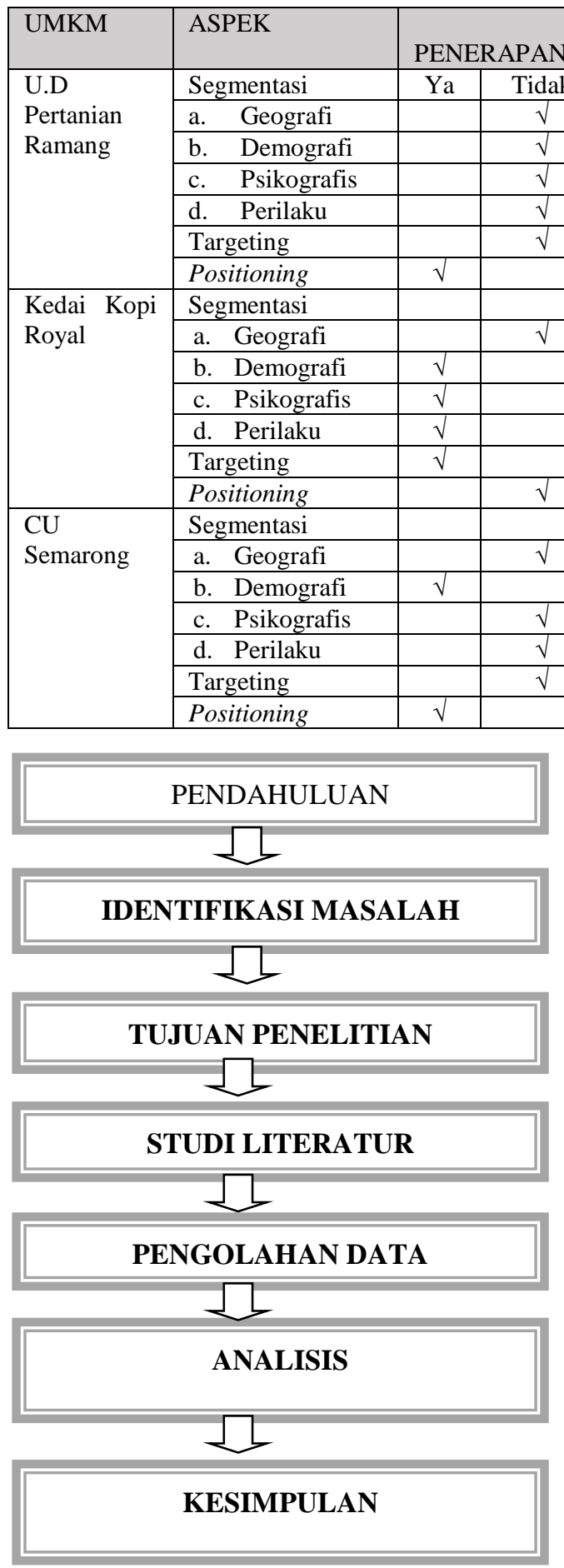

Gambar 2. Tahap Metode Penelitian 


\section{PEMBAHASAN}

Disajikan dan pembahasan dalam penelitian ini

\subsection{Analisis Penerapan aspek Segmentasi pada UMKM Kota Bengkayang}

Salah satu strategi yang dilakukan oleh pemerintah dalam menopang pembangunan ekonomi di kabupaten Bengkayang yaitu memberdayakan dan menumbuhkan Usaha Mikro Kecil dan Menengah (UMKM). (Manggu \& Beni, 2019). Usaha Mikro Kecil Menengah (UMKM) di kota Bengkayang meliputi perdagangan, jasa yang terdiri dari keuangan, hotel, kesehatan, usaha kerajinan tangan, pertanian, perkebunan. Jika dilihat dari potensi sumber daya seharusnya segmentasi disesuaikan dengan kondisi potensi. Menetapkan segmentasi pasar, berdasarkan daerah asal, tempat tinggal konsumen, sepanjang pengamatan penulis, sebagian Usaha Mikro Kecil Menengah (UMKM) belum memetahkan segmentasi berdasarkan hal tersebut diatas, dan masih menerapkan pasar secara keseluruhan, jika dilihat dari potensi sumber daya seharusnya segmentasi disesuaikan dengan kondisi yang paling relevan. Agar strategi penerapan segmentasi tepat, Usaha Mikro Kecil Menengah (UMKM) memandang dari sudut yang unik dan dengan cara yang berbeda dari yang dilakukan pesaing, mencerminkan perilaku pembelian atau penggunaan serta menentukan alasan pelanggan untuk membeli. Berdasarkan hasil pengamatan Usaha Mikro Kecil Menengah (UMKM) di kota Bengkayang penerapan Segmentasi, Targeting, Positioning (STP) bertujuan untuk memposisikan merk di benak konsumen, sehingga merek tersebut memiliki keunggulan yang kompetitif yang berkesinambungan. Menurut Fandy (2011) bahwa sebuah produk memiliki keunggulan kompetitif jika produk tersebut menawarkan atributatribut yang bernilai penting di pelanggan.

\subsection{Analisis Penerapan Targeting pada UMKM Kota Bengkayang}

Dalam mengevaluasi Segmen pasar yang berbeda perusahaan harus melihat dua faktor yaitu daya tarik pasar secara keseluruhan serta tujuan dan resource perusahaan (Kotler, 2011). Usaha Mikro Kecil Menengah (UMKM) di kota Bengkayang setidaknya melihat apakah segmen potensial memiliki karakteristik yang secara umum menarik seperti ukuran, pertumbuhan, profitabilitas, skala ekonomi, risiko yang rendah dan lain-lain. Keraguan Usaha Mikro Kecil Menengah (UMKM) untuk berinvestasi ke dalam target segmentasi yang diharapkan karena keterbatasan sumber daya yang dimiliki. Kartajaya, Huan dan Liu (2003) menyatakan ada tiga kriteria yang harus dipenuhi perusahaan pada saat mengevaluasi dan menentukan target, segmen pasarpasar yang dibidik itu cukup besar dan menguntungkan bagi perusahaan, strategi targeting itu harus didasarkan pada keunggulan kompetitif perusahaan, segmen pasar yang dibidik harus didasarkan pada situasi persaingan. Belum mampu Usaha Mikro Kecil Menengah (UMKM) di Kota Bengkayang menargetkan pasar yang lebih luas, hanya sebatas kemampuan yang dimiliki, mengingat faktor sumber daya, finansial, sumber daya masih terbatas. Sebagian para pelaku UMKM masih menawarkan produk untuk di jual dan laku, belum mempertimbangkan rencana strategis untuk bertahan di pasar. Minimnya memahami perilaku para konsumen, keraguan untuk pengembangan pasar dalam hal ini membidik pasar yang dimasuki belum diterapkan oleh sebagian pelaku Usaha Mikro Kecil Menengah (UMKM). Dengan adanya pasar yang dibidik dapat membuat pelaku Usaha Mikro Kecil Menengah (UMKM) fokus promosi, perbaikan produk, menciptakan keunggulan yang kompetitif.

\subsection{Analisis Penerapan aspek Positioning pada UMKM Kota Bengkayang}

Produk yang ditawarkan kepada konsumen agar lebih muda, para pelaku Usaha Mikro Kecil Menengah (UMKM) senantiasa selalu meningkatkan citra, persepsi, dan imajinasi. Memposisikan produk di benak konsumen agar selalu diingat, merupakan salah satu penentu keberhasilan. Usaha Mikro Kecil Menengah (UMKM) di kota bengkayang untuk membedakan dengan yang lainnya melalui, cara kerja, kinerja, kualitas, brand (kemasan, logo, pelayanan, tempat, logo. Image atau citra terbentuk di benak seorang konsumen da sebuah nama perusahaan atau produk, Positioning adalah bagaimana sebuah produk di mata konsumen yang membedakannya dengan produk pesaing. Dalam hal ini termasuk brand image, manfaat yang dijanjikan serta competive advantage, Fanggidae, (2006) menyatakan positioning adalah suatu strategi dalam kegiatan pemasaran yang bertujuan untuk menciptakan perbedaan, keuntungan, manfaat yang membuat konsumen selalu ingat dengan produk. Dalam menentukan positioning ada empat tahap, nilai bagi konsumen, penentu bagi konsumen pada saat memutuskan untuk membeli, kajian pada kapabilitas Menempatkan produk di benak konsumen agar selalu diingat ketika konsumen menggunakannya, positioning ini berdasarkan cara kerja, kinerja, kualitas, brand (kemasan, logo, pelayanan, tempat, logo. Belum fokusnya manfaat yang diterima oleh pelanggan dari segi nilai, tidak adanya sesuatu yang membawa keunikan dari para pesaing, tidak adanya kredibilitas, yang menunjukkan sikap kepercayaan sebuah brand di mata konsumen, kesesuaian posisi brand dengan perusahaan. Pembedaan ini salah satu untuk memudahkan pelaku Usaha Mikro Kecil Menengah (UMKM) untuk memasarkan produknya dan Usaha Mikro Kecil Menengah (UMKM) itu semakin berkembang. Usaha Mikro Kecil Menengah (UMKM) Perlu membuat positioning yang tepat untuk perusahaan maupun produknya. Bagi pelanggan positioning diperlukan untuk membangun kepercayaan pelanggan pada produk. Promosi penjualan, menyampaikan produk yang dihasilkan oleh pelaku UMKM agar dapat digunakan atau dimanfaatkan untuk memenuhi 
kebutuhannya dalam beberapa waktu, dengan tujuan untuk meningkatkan penjualan, merangsang permintaan pasar atau meningkatkan ketersediaan produk. Promosi yang dilakukan para pelaku Promosi Penjualan sebagian besar masih menggunakan cara tradisional, menjual dan laku, sehingga konsumen belum dapat dijangkau secara maksimal terutama kepada konsumen yang berpotensi, tidak banyaknya konsumen baru karena promosinya masih minim. Pentingnya memasarkan produknya melalui sarana yang mudah dan terjangkau terutama melalui digital marketing dapat memudahkan dan biaya yang sangat minim. Memudahkan para pelaku untuk memanjakan konsumennya sebagai bentuk pelayanan. Promosi dari mulut ke mulut, referensi keluarga, teman, hal itulah yang diandalkan oleh pelaku dalam meraih konsumen. Keraguan untuk menggunakan sarana yang ada disebabkan oleh faktor individu, menyangkut dengan aturan yang diterapkan oleh pemerintah daerah. Promosi ini dapat dilakukan oleh pelaku Usaha Mikro Kecil Menengah (UMKM) secara fisik, media tradisional, digital.

\section{KESIMPULAN}

Hasil dari pada penelitian ini bahwasanya para pelaku Usaha Mikro Kecil Menengah (UMKM) di kota Bengkayang masih belum fokus untuk menargetkan konsumen yang akan dipilih, karena dilihat dari jenis usaha, para pelaku Usaha Mikro Kecil Menengah (UMKM) di kota bengkayang masih sebatas mengikuti pasar, belum ter-konsep untuk menghadapi persaingan. Pada umumnya karakteristik konsumen di kota Bengkayang memiliki perbedaan kebutuhan, karakteristik, ataupun perilaku yang berbeda di dalam pasar tertentu. Dengan fokus melayani pasar yang dituju lebih mudah membedahkan pasar yang akan kita raih, pelayanan akan lebih maksimal, strategi yang dilakukan oleh pelaku Usaha Mikro Kecil Menengah (UMKM) lebih terarah, adanya temuan peluang baru dalam berusaha, mendesain akan usaha yang dilaksanakan, komunikasi lebih baik dan dapat berjalan, melihat competitor dengan segmen yang sama, evaluasi akan target dan rencana bisnis, memasarkan produknya dan mengetahui jelas akan karakteristik konsumen yang dituju. Begitu juga dengan penerapan segmentasi pasar, para pelaku Usaha Mikro Kecil Menengah (UMKM) belum memetahkan pasar berdasarkan geografi, kebanyakan para pelaku Usaha Mikro Kecil Menengah (UMKM) target market di kota, padahal dilihat dari potensi para konsumennya mendiami perkampungan, pedesaan, dan kecamatan, rata-rata berpotensi dengan karakteristiknya berbeda usia, jenis kelamin, tingkat ekonomi, tingkat pendidikan, juga merupakan hal yang penting untuk di lihat juga agar target dapat dicapai. Belum adanya target berdasarkan demografi menyebabkan kurang begitu berkembang usaha yang dilakukan, karena mayoritas penduduk yang ada di Kota bengkayang terdiri dari suku, agama dan ras yang berbeda, dimana suku dayak merupakan suku yang terbesar, berikut melayu, cina, jawa dan beberapa suku lainnya. Seharusnya pelaku Usaha Mikro Kecil Menengah (UMKM) mengetahui akan karakteristik dari konsumen yang mendiami kota bengkayang, perilakunya, penggunaan akan produk, tingkat pemakaiannya seberapa jauh, jelas harus diamati. Masih adanya para pelaku Usaha Mikro Kecil Menengah (UMKM) belum memposisikan usahanya untuk berbeda dengan yang lain, ini terlihat dari belum dibuatnya logo, kemasan, banner, brosur, tempat berdirinya usaha yang strategis dan layak, kekurangan aspek tersebut dapat menyebabkan konsumen ragu untuk memakai atau menggunakan produk yang dihasilkan. Promosi yang dilakukan para pelaku Usaha Mikro Kecil Menengah (UMKM) sebagian besar masih menggunakan cara tradisional, menjual dan laku, sehingga konsumen belum dapat dijangkau secara maksimal terutama kepada konsumen yang berpotensi, tidak banyaknya konsumen baru karena promosinya masih minim.

\section{SARAN}

Para pelaku UMKM membagi kelompok pembeli yang memiliki perbedaan kebutuhan, karakteristik atau perilaku yang berbeda dalam pasar tertentu, dengan adanya pembedaan ini para pelaku UMKM dapat dengan jelas mengetahui akan kebutuhan dan fokus akan pelayanan konsumen yang dituju. Berdasarkan pengamatan penulis, para pelaku UMKM masih belum menerapkan segmenting yang memiliki potensi besar terutama dalam hal geografi, dimana banyak desa yang memiliki potensi, tetapi para pelaku UMKM hanya berpusat pada konsumen yang ada di kota, masih menerapkan mas marketing, artinya targetnya belum fokus berdasarkan usia, jenis kelamin, tingkat ekonomi, dan pendidikan, begitu juga dengan sociocultural, belum adanya para pelaku Usaha Mikro Kecil Menengah (UMKM) untuk melihat pasar yang dituju berdasarkan budaya. Para pelaku Usaha Mikro Kecil Menengah (UMKM) di Kota Bengkayang hanya mengandalkan segmentasi berdasarkan benefit, dan segmentasi berdasarkan situasi dan penggunaan,

Para pelaku Usaha Mikro Kecil Menengah (UMKM) sebaiknya memasarkan produknya terpusat pada kelompok pembeli potensial yang lebih menguntungkan, dengan harapan mendapatkan posisi yang kuat dalam kelompok pembeli, dan hemat biaya dalam mengoperasikan. Pemosisian produk sangatlah penting, para pelaku Usaha Mikro Kecil Menengah (UMKM) sebaiknya menciptakan sesuatu yang berbeda dengan Usaha Mikro Kecil Menengah (UMKM) lainnya, adanya Brand yang meliputi, logo, kemasan, brosur, banner, tempat usaha yang tertata rapi. Adanya brand ini memudahkan konsumen membedahkan produk, lebih mudah dalam penjualan, adanya kepastian legal, dan tentunya produknya semakin diterima oleh konsumen. Promosi penjualan yang dilakukan sebaiknya dilakukan dengan semenarik mungkin, dengan cara model pemasaran yang terintegrasi yang meliputi periklanan, e 
marketing, internet, acara dan pengalaman, layanan pelanggan. Saran bagi peneliti selanjutnya meneliti dari sisi penerapan Branding UMKM, karena sangat penting untuk bertahan di tengah persaingan usaha yang sejenis.

\section{DAFTAR PUSTAKA}

Assari, S. (2013). Manajemen Pemasaran, Dasar Dan Konsep. Jakarta: CV Rajawali.

Boon, K. (. (2008). Contemporary Marketing 14 th. New York: Sount-West.

Durianto, D. (2013). Strategi Menaklukkan Pasar Melalui Rset Ekuitas dan Prilaku Merk. Jakarta: Gramedia Pustaka Utama.

Durianto, dkk. 2013. Strategi Menaklukkan Pasar Melalui Rset Ekuitas dan Prilaku Merk. Jakarta: Gramedia Pustaka Utama.

Fandy, T. (2011). Pemasaran jasa. Malang: Bayumedia.

Fanggidae, A. H. (2006). Strategi Pemasaran Pariwisata: Segmentation ,target market ,positioning,dan marketing mix. Kupang: Fisip Universitas Nusa Cendang.

Firmansyah, M. A. (2019). Pemasaran: Dasar dan Konsep. Penerbit Qiara Media.

Keller, K. L., \& Kotler, P. (2012). Branding in B2B firms. In Handbook of business-to-business marketing. Edward Elgar Publishing.

Kotler, P. (2011). Grundlagen des marketing (Vol. 1). Pearson Deutschland GmbH.
Kotler, P. (2012). Kotler on marketing. Simon and Schuster.

Maliki, Z. (2018). Sosiologi politik: makna kekuasaan dan transformasi politik. UGM PRESS

Manggu, B., \& Beni, S. (2019). Pelaksanaan E-Mar Keting Usaha Mikro Kecil Menengah (UMKM) Sebagai Stragi Untuk Meningkatkan Penjualan (Studi Kasus UMKM Di Kota Bengkayang Kalimantan Barat. Sebatik, 23(2), 455-461.

Rismiati, E. C., \& Suratno, I. B. (2001). Pemasaran Barang dan Jasa. Penerbit Kanisius.

Sihotang, J. P. (2017). Analisis Strategi Segmenting, Targeting Dan Positioning Pada Perushaan Asuransi Pt. (persero) Jiwasraya, Pekanbaru. JOM FISIP, IV (STP), -.

Stanton, W., J. (2013). Prinsip Pemasaran Jild 1 Edisi 10. Jakarta: Erlangga.

Undang-Undang No. 70 Tahun 2008 Tentang Usaha Mikro Kecil Menengah . n.d.

Wijaya, H., \& Sirine, H. (2016). Strategi segmenting, targeting, positioning serta strategi harga pada perusahaan Kecap Blekok di Cilacap. Asian Journal of Innovation and Entrepreneurship, 1(03), 175190.

UCAPAN TERIMA KASIH

Ucapan terima kasih peneliti sampaikan kepada Institut Shanti Bhuana 